\title{
Geisel, Figueiredo e a Liberalização do Regime Autoritário (1974-1985)
}

\author{
Aloysio Carvalho
}

E $m$ um depoimento concedido a historiadores sobre sua trajetória no regime autoritário de 64, o ex-presidente Geisel admitiu a tortura como um meio necessário para a obtenção de confissões. O general reconheceu que "há circunstâncias em que o indivíduo é impelido a praticar a tortura, para obter determinadas confissões e, assim, evitar um mal maior" (D'Araújo e Castro, 1997:225). A revelação de Gei$\mathrm{sel}^{1}$, o quarto general a exercer o poder após a deposição do presidente João Goulart, coloca em questão a imagem do dirigente militar comprometido com a legalidade e com a condenação dos excessos de violência praticada pelo aparato repressivo, sob controle da linha dura. Desse modo, abrem-se novas vias de pesquisas sobre um dos períodos mais sombrios da história republicana brasileira no século XX. Ressurgem as polêmicas não apenas sobre as razões da liberalização, mas também com relação aos papéis desempenhados pelos grupos militares na organização do regime que se tornou conhecido por sua longa duração. De fato, em comparação com seus similares na América Latina, o regime autoritário brasileiro distinguiu-se pela prolongada existência e preservação da capacidade de intervenção militar, com a presença no poder de um grupo dirigente voltado para a questão da institucionalização política, seja ao assumir a condução do Estado em 1964, seja ao comandar a lenta transição até a constitui-

DADOS - Revista de Ciências Sociais, Rio de Janeiro, Vol. 48, nº1, 2005, pp. 115 a 147. 
ção de um governo civil em 1985. Este trabalho discute a evolução do regime de uma perspectiva histórica, enfatizando os conflitos e os dilemas enfrentados nesse período pelos militares enquanto governo. Pressupõe que os dirigentes buscaram ampliar a legitimidade do regime quando se decidiram pela liberalização, que foi implementada no rastro de um momento favorável da economia e encontrou condições para se viabilizar e se desdobrar em uma transição negociada em virtude das tradicionais instituições do sistema político não terem sido eliminadas, mas manipuladas sob controle autoritário. Isso possibilitou, a partir de 1974, a revitalização dos mecanismos representativos clássicos, eleitorais e partidários, quando foram ampliados os canais de comunicação com a sociedade.

Uma das características marcantes do autoritarismo que emergiu no Brasil em 1964 consistiu no poder de decisão que os militares, como integrantes do aparelho estatal, adquiriram e expandiram em relação aos atores do sistema político e da sociedade civil. O fato de se tornarem os atores principais do processo político não significa que as Forças Armadas, enquanto instituição, estivessem diretamente envolvidas em todas as decisões com relação à economia ou outras questões da administração do governo. Embora se saiba que por volta de 1979 27,8\% dos cargos civis da administração federal, direta e indireta, fossem preenchidos pelo pessoal militar (Góes, 1988:237), a posição de destaque conquistada pela instituição militar no âmbito do Estado traduziu-se principalmente no poder de veto sobre as grandes decisões, sendo a mais importante a sucessão presidencial (Cardoso, 1982:48) Nesse sentido, houve uma mudança no papel da organização militar, que se transformou no eixo em torno do qual giravam as opções estratégicas do Estado. As diretrizes gerais para a formulação de políticas substantivas passaram a depender da busca pelo consenso na opinião militar, sobretudo do Exército (Coelho, 1976:165), a corporação dominante no esquema de poder.

A intervenção direta na condução da política provocou conflitos entre as Forças Armadas e as decisões dos militares como governo. Desde 1964 foram visíveis as divergências entre correntes militares sobre a organização do tipo de regime. A sucessão presidencial provocava momentos de aguda tensão no meio militar, apesar do rodízio no poder ter sido adotado como procedimento do regime. A disputa final pelo controle do governo estimulava nas Forças Armadas a formação de facções. A partidarização do aparelho militar pode ter atingido seu 
ponto de maior intensidade após a doença do presidente Costa e Silva em agosto de 1969, quando em seguida assumiu o poder uma junta integrada pelos ministros de Exército, da Marinha e da Aeronáutica. O sucessor de Costa e Silva, o general Médici, foi escolhido pela oficialidade em um escrutínio reservado aos oficiais das três armas (D'Araújo e Castro, 1997:211, 213), em flagrante desrespeito às regras sucessórias estabelecidas pela Constituição de 1967. Todavia, a escolha de Médici para assumir a presidência representou um amplo acordo do qual teria feito parte até mesmo a corrente castelista, que perdera posições de poder desde a eleição de Costa e Silva ${ }^{2}$. Desse modo, o desfecho sucessório em favor do apartidarismo do general Médici significaria mais do que o fim das pretensões do seu competidor, o candidato general Albuquerque Lima, tido na época como integrante da linha dura e nacionalista de direita. Acabou reforçando o clima de coesão que se criara entre os militares do governo e as Forças Armadas desde a decretação do Ato Institucional nº 5 - AI-5 (Cruz e Martins, 1983).

No âmbito das transformações do regime autoritário, que ora tendia à cisão, ora à unidade das Forças Armadas, elaborava-se o discurso da liderança, articulado aos princípios da Doutrina de Segurança Nacional e Desenvolvimento e à concepção de que as corporações militares e os valores de disciplina e hierarquia constituíam um modelo superior para organizar a sociedade e integrar a nação. Formulada pela Escola Superior de Guerra, criada em 1949, a doutrina atribuía uma conotação negativa aos conflitos sociais, interpretando-os como ameaças à segurança interna e ao desenvolvimento nacional ${ }^{3}$. Os militares que lideraram o golpe de Estado em 1964 associavam a indisciplina nas Forças Amadas à indisciplina na nação. Influenciados pela idéia de que não se deve fazer política no Exército, mas a política do Exército, eles viam nas Forças Armadas o intérprete maior dos interesses da nação e consideravam a intervenção uma missão constitucional, necessária para preservar o Estado. De conteúdo conservador, a Doutrina de Segurança Nacional não apenas justificava a tutela da sociedade pelo argumento de que sua natureza conflituosa confrontava o projeto de elevar o Brasil ao patamar de potência capitalista ocidental, mas criava no contexto de Guerra Fria e de uma suposta guerra revolucionária comunista a base comum para a definição dos critérios sobre os quais foram tomadas as decisões dos governos militares. Cabe lembrar que a paulatina ampliação das características autoritá- 
rias do Estado - observadas, sobretudo, depois de 1968 com a decretação do AI-5, o fechamento do Congresso e a expansão do aparato repressivo - foi antecedida por instabilidades políticas, conjugadas a agudas divergências e crises nas Forças Armadas. Havia um ambiente de contestação ao regime que se expressou tanto pela organização extra-institucional da Frente Ampla e derrota do governo no Congresso no caso Márcio Moreira Alves, quanto pelas greves operárias em Osasco e Contagem e pelas mobilizações lideradas por grupos de esquerda que organizaram passeatas estudantis e protestos de segmentos da classe média.

Nesse sentido, ao lado da redefinição das regras do regime e dos procedimentos de participação é preciso considerar a atuação do aparelho repressivo do Estado, pois a escolha da força como meio privilegiado para obter obediência às normas políticas exigiu que os órgãos de segurança ocupassem um lugar de destaque. Se estabelecermos uma hierarquia entre os componentes institucionais da estrutura repressiva de acordo com a responsabilidade de conter a contestação à ordem autoritária, verificaremos que os serviços secretos se encontravam em primeiro plano em comparação à justiça militar, à Lei de Segurança Nacional e à censura. Detentores dos segredos vitais do Estado, os órgãos de inteligência constituíram no Brasil pós-64 um dos núcleos centrais do poder. A noção de um poder organizado segundo os princípios da não-transparência, da não-visibilidade, ganha sua exata dimensão quando resgatamos os ensinamentos de Hannah Arendt sobre a polícia secreta de Hitler, o mais importante órgão do esquema de dominação nazista. Segundo a filósofa, "a única regra segura num Estado totalitário é que, quanto mais visível é uma agência governamental, menos poder detém; e, quanto menos se sabe da existência de uma instituição, mais poderosa ela é" (Arendt, 1979:153). Guardadas as devidas diferenças em relação aos serviços secretos do Estado totalitário na Alemanha - pela preparação ideológica de seus quadros, pelo domínio ilimitado sobre todos os ramos do aparelho repressivo, inclusive o Exército, e pela brutalidade dos crimes cometidos contra a humanidade-, esse verdadeiro poder no Brasil pós-64 simbolizou, na sua forma, a essência do regime anti-republicano e autoritário, ficando sua montagem e comando sob responsabilidade dos militares. Os diversos órgãos da polícia política constituíam o que se chamava de comunidade de inteligência, onde se destacava o Serviço Nacional de Informações - SNI, comandado por oficiais generais do Exército. O 
SNI não era um órgão executante, porém o mais importante órgão de informação pelas prerrogativas de que dispunha para vigiar e acompanhar áreas da sociedade civil, política e do próprio aparelho de Estado, incluindo os serviços de inteligência das Forças Armadas (Stepan, 1986) espalhados por diversas regiões do país.

Conectada aos três ramos das Forças Armadas, criou-se também uma rede de serviços secretos com unidades especializadas: Centro de Informações do Exército - CIE, Destacamento de Operações de Informações - DOI, Centro de Operações de Defesa Interna - CODI pertencentes ao Exército, Centro de Informações da Marinha - CENIMAR à Marinha e Centro de Informações de Segurança da Aeronáutica CISA à Aeronáutica. A forma como os organismos de repressão executavam suas ações provocou impacto em setores da sociedade e na estrutura da autoridade militar. O desgaste das corporações com denúncias de torturas e desaparecimentos de presos políticos foi o capítulo mais visível dessa história de violência do Estado. Uma questão de menor transparência diz respeito à erosão da hierarquia militar provocada pela maior autonomia conquistada pelos órgãos de repressão de acordo com a importância assumida no combate à contestação aos governos. A rivalidade e a competição pelas informações, bem como a necessidade de segredo nas operações e de rapidez nas investigações, levavam os organismos a rejeitar a cadeia oficial de comando a qual deveriam submeter-se e prestar contas. Documentos do SNI produzidos no governo Geisel evidenciam que faltava "coordenação entre os Centros de Informações Militares ou até mesmo entre o CIE e os DOI/Ex" (Castro, 2002:52). Relatos de Geisel dão conta de que o CIE do Exército sonegava informações ao SNI, dificultando o acompanhamento das operações que deveriam ser comunicadas ao presidente. Criado por Costa e Silva em 1967 à semelhança do que existia na Marinha com o CENIMAR e na Aeronáutica com o CISA, o CIE tornou-se o órgão mais poderoso do aparato repressivo. Sua criação, no entanto, foi um erro, disse Geisel, pois levou a uma superposição, abrindo-se "um processo de descentralização que ia permitir que as ações particulares ou isoladas desenvolvidas por esses órgãos fugissem ao controle da presidência" (D'Araújo e Castro, 1997:228). Por causa da autonomia adquirida tanto no Estado como na própria corporação, o general Golbery chegou a declarar que a comunidade de segurança se tornara perigosa no final de 1973. Em uma série de entrevistas concedidas a Alfred Stepan sobre os motivos da liberalização 
no Brasil, o idealizador e criador do SNI disse que a autonomia e a radicalização das forças de segurança, originadas da campanha antiguerrilha de 1969-72, apresentavam uma dupla ameaça aos militares. Os perigos da dominância da comunidade de segurança encontravam-se na possibilidade de "fragmentação" dos militares e de "distanciamento cada vez maior entre as forças fundamentalmente moderadas da sociedade brasileira e os militares brasileiros" (Stepan, 1986:48).

A violência praticada pelos órgãos repressivos do Estado sempre foi cultivada pelos dirigentes militares, situando-se no centro da estratégia para consolidar o autoritarismo cujo propósito era desmobilizar e despolitizar a sociedade. Todavia, a violência atingiu formas extremas de ilegalidade, chegando a adquirir traços que a aproximasse do terrorismo totalitário como ocorreu entre 1969 e 1973. O Estado expandiu o perfil policial no controle da sociedade e os indivíduos perderam por completo as garantias legais, ficando desprotegidos ante as ameaças dos aparatos de segurança que não conheciam limites para as suas operações. A falta de controle dessa estrutura paralela de poder, evidenciada pelas declarações de Geisel e Golbery, ficou mais visível após 1969, quando foram ampliadas as atividades de planejamento e execução das tarefas repressivas para conter os opositores, sobretudo a esquerda armada.

O recrudescimento das formas autoritárias de poder com a decretação do AI-5 e a expansão das ações repressivas comandadas pelas forças de segurança criaram um clima de que seria longa, até eterna para alguns, a permanência das Forças Armadas na arena política. Isso explica por que o tempo dos militares no controle do poder se tornou durante o governo Médici um dos assuntos discutidos na Escola Superior de Guerra -ESG, ganhando publicidade na imprensa. Dirigentes comprometidos com uma posição mais moderada mantiveram o discurso construído logo após o golpe de 64 , segundo o qual a intervenção militar deveria ser limitada no tempo. Em palestra proferida em 1971 na ESG, o ministro do Planejamento do governo Castelo, Roberto Campos, articulou a demanda de diminuição do componente de coação do Estado com a proposição de que as Forças Armadas não deveriam promover uma escalada da intervenção estabilizadora para um tipo de intervenção autocrática, pois isso implicaria uma reconsideração do problema da institucionalização política. Nessa linha de argumentação, o chefe do Estado Maior do Exército introduziu no ce- 
nário público no final de 1971 o discurso que preservava o compromisso com o fim do ciclo militar e o restabelecimento do caráter profissional dos membros das Forças Armadas. O general Souto Malan afirmou que "estava [...] à vista o momento em que a existência de quadros suficientemente amplos [...] permitiria aos militares concentrar-se no exercício de sua profissão." Segundo o general, "podemos permitir-nos prospecções sobre o processo que se chamaria de desengajamento controlado das Forças Armadas"4. Esta declaração veiculada pelo Jornal do Brasil teve grande repercussão na opinião pública, uma vez que foi emitida na presença do ministro do Exército, general Orlando Geisel, por ocasião da entrega da espada aos novos generais, alimentando expectativas de que seriam restabelecidos alguns dos princípios liberais que antes haviam orientado os processos de governo ${ }^{5}$.

O autoritarismo militar contemporâneo no Brasil não eliminou as tradicionais formas de expressão política. Adotou-se uma ordem política híbrida na qual formas autoritárias de poder conviviam com a limitada autonomia das instituições liberais representativas. Todavia, foram introduzidas mudanças no quadro partidário e o sistema eleitoral foi manipulado de modo que a competição política fosse reduzida e os resultados eleitorais garantissem vantagens ao partido governamental $^{6}$. O Parlamento foi mantido aberto - exceto por três períodos (outubro de 1966, dezembro de 1968 a outubro de 1969 e abril de 1977) -, mas a instituição viu sua participação diminuída gradativamente na formulação e legislação de políticas. Um exame detalhado da Constituição de 1967, que incorporou os controles autoritários mais importantes dos atos institucionais anteriores, mostraria que esse contrato idealizado pela corrente castelista acentuou a tendência de organizar um Estado fundamentalmente baseado no poder Executi$\mathrm{vo}^{7}$. A relação entre as instituições centrais (incluindo o Judiciário) indicava a configuração de um quadro que poderíamos denominar de ditadura do Executivo, pela inexistência de controles mútuos entre os poderes. Com a crise de 1968, contudo, se seguiria uma nova mudança de qualidade no exercício desses poderes, uma vez que após a instituição do AI-5 ocorreria uma ruptura entre processos de governo e processos parlamentares. O governo passou a dispensar a colaboração do Congresso na formulação, discussão e decisão sobre políticas públicas (Santos, 1978:81). 
Com o fechamento do Congresso após a crise de 1968 e a suspensão do projeto mais moderado manifestado na Constituição de 1967, a estratégia de alcançar a legitimação principalmente pelo desempenho econômico tomou força. Na verdade, a prioridade da ordem econômica em relação à ordem política já se achava presente na fase de implantação do regime. Castelo Branco iniciou seu governo dedicado a promover medidas institucionais que visassem reorganizar a administração econômica. A partir dos bons resultados alcançados - restauração da credibilidade externa, controle do déficit público e da inflação e retomada do crescimento - esperava-se encontrar as condições adequadas para a reorganização da competição política ${ }^{8}$. Nesse tempo inicial, o cumprimento do calendário eleitoral foi alvo de acirrados debates internos. Existia um clima favorável à defesa da idéia de que as eleições de 1965 poderiam tornar-se um plebiscito sobre o novo regime. Havia dúvidas sobre o apoio que o governo poderia alcançar na opinião pública em virtude dos custos políticos provocados pelas cassações de parlamentares, pelos expurgos no interior da burocracia civil e militar e pela repressão sobre as organizações sindicais e estudantis. Cabe lembrar, sobretudo, que o programa de estabilização econômica, comandado pelos ministros Octavio Gouveia de Bulhões e Roberto Campos, era considerado "duro e difícil", segundo palavras de Geisel, para quem as medidas de austeridade teriam provocado "uma certa recessão", causando "dificuldades na indústria e no comércio" (D'Araújo e Castro, 1997:173).

A estratégia dos governos militares foi, portanto, a de associar a meta de crescimento econômico, com base no estilo tecnocrático de gestão, ao controle burocrático autoritário da política. Com o esvaziamento do Legislativo como lugar em que os partidos representavam múltiplos interesses, formulavam políticas e compartilhavam o poder, a participação no interior da máquina governamental foi reforçada (Lafer, 1975). O Conselho Monetário Nacional criado em 1964 constitui um dos exemplos de como um órgão governamental ocupou lugar privilegiado para onde convergiam as demandas de diversos segmentos do empresariado, "transformando-se numa arena de negociação entre setor público e privado, cabendo à tecnocracia o papel de agente mediador dos interesses privados" (Diniz, 1994:209). Mais do que uma autoridade na formulação da política monetária e creditícia, esse órgão passou a dirigir de fato a política econômica do país, tornando-se o responsável pela administração do "milagre econômico" 
ocorrido no governo Médici. Presidido pelo ministro da Fazenda Delfim Netto, o Conselho Monetário Nacional variou a sua composição, contando com ministros da área econômica, presidentes de instituições financeiras e representantes da iniciativa privada como membros nomeados (idem:208).

Enquanto foram concedidas oportunidades para setores da classe dominante expressarem suas demandas, os representantes da classe trabalhadora foram excluídos da participação ou da possibilidade de influência nos órgãos decisórios do governo. Inicialmente vale lembrar o caso do Conselho Consultivo de Planejamento, no governo Castelo Branco. O órgão de assessoria ao Ministério Extraordinário para o Planejamento, no qual estava prevista a participação de representantes de sindicatos de trabalhadores, foi esvaziado de sua função (Cruz, 1978). Além de os representantes dos trabalhadores encontrarem obstáculos formais de acesso aos centros decisórios, pois não estava prevista sua participação nos outros colegiados de planejamento, como o Conselho Monetário Nacional e o Conselho de Desenvolvimento Econômico (Diniz e Lima Junior, 1986), os governos militares cercearam a liberdade e autonomia do movimento sindical. Foram aplicadas de forma rigorosa antigas medidas legais previstas na Consolidação das Leis do Trabalho - CLT, a legislação trabalhista herdada dos anos da ditadura varguista (Almeida, 1983). A repressão burocrática-legal dos governos militares visou subordinar ao Ministério do Trabalho as ações político-organizacionais dos trabalhadores. A intervenção nos sindicatos, o afastamento de dirigentes eleitos, bem como a anulação de eleições e o veto a candidaturas estavam entre as prerrogativas do Ministério, que também reconhecia os sindicatos, possibilitando seu funcionamento oficial. O caráter repressivo e de classe do Estado capitalista adquirido após 1964 fica ainda mais nítido se considerarmos que o controle sobre a força de trabalho foi exercido não somente por meio de uma lei de greve que na prática proibia o uso desse instrumento de luta: as perseguições e prisões também fizeram parte do cotidiano dos líderes operários e sindicais.

O mais alto grau de coerção política manifestou-se no decorrer do governo Médici, quando a economia sob o comando do ministro da Fazenda Delfim Netto apresentou um crescimento surpreendente, consolidando um tipo de desenvolvimento que privilegiava a grande empresa nacional, estatal e multinacional. As questões relativas ao crescente endividamento externo do país e a deterioração na distri- 
buição de rendas ${ }^{9}$ ficaram em segundo plano diante do controle da inflação e do aumento das exportações, garantido pelos incentivos governamentais e por um mercado mundial favorável. A expansão da economia brasileira refletiu-se nos indicadores do Produto Interno Bruto - PIB que subiu em torno de $11 \%$ ao ano entre 1970 e 1973. Para estimular a indústria, Delfim Netto expandiu o sistema de crédito ao consumidor e garantiu à classe média o acesso aos bens de consumo duráveis - de automóveis a aparelhos eletrodomésticos. Este setor, prioritário das políticas econômicas, canalizou uma parcela significativa dos altos investimentos estrangeiros, que, em termos globais, passaram de cerca de US $\$ 11,4$ milhões para mais de US $\$ 4,5$ bilhões entre 1968 e 1973 (Alves, 1989:148). Estudos mostram que em função do desempenho da economia, na década de 70, o emprego urbano cresceu a uma taxa mais elevada $(6,42 \%$ ao ano) que a população urbana (4,83\% anuais). Na criação de empregos na década de 70 , o setor secundário - indústria de transformação, construção civil e outras atividades industriais - superou o setor terciário, de serviços sociais e pessoais (Faria, 1983:151).

As taxas de rápido crescimento industrial facilitaram a construção da imagem de um país dinâmico que havia modernizado sua estrutura capitalista e promovia uma arrancada econômica. Os resultados favoráveis na economia criaram um clima de euforia, sobretudo entre segmentos da classe média e do empresariado e contribuíram para que os representantes do autoritarismo apresentassem propostas diante das controvérsias sobre os benefícios do modelo político instituído após o AI-5. Ao despedir-se da vida pública em dezembro de 1970, o senador Mem de Sá (ARENA-RGS)*, por exemplo, reafirmou sua fé no regime e disse que a "democracia plena, a que é estável e liberta de subversões, golpes e eclipses, esta apenas nos chegará através do desenvolvimento econômico". Identificado como um político solidário às teses do poder, o ministro da Justiça de Castelo Branco na fase pós-AI-2 reiterava, assim, a necessidade de manter a prioridade do econômico sobre o político e apontava o caminho do fortalecimento do governo, de modo a assegurar a continuidade do desenvolvimento $^{10}$. A proposição do senador não teria causado tanta repercussão caso o país não vivesse uma fase de crescimento econômico, ao lado da mais total falta de perspectiva em direção às liberdades. No dia se-

\footnotetext{
* Ver Glossário no final deste artigo.
} 
guinte à sua publicação pela imprensa, ela seria comentada pelo Jornal do Brasil em editorial intitulado "Doutrina Perigosa", segundo o qual "a tese do senador era no mínimo temerária e, em última análise, consistia em dizer que a democracia seria um luxo proibido para as nações subdesenvolvidas"11. Esse tipo de formulação adotada pelo representante da imprensa liberal carioca chamava atenção para o fato de que as realizações no plano econômico não deveriam obscurecer a rigidez do sistema político. Embora o governo Médici encontrasse resultados favoráveis na economia, vivia-se o tempo de maior restrição à participação e influência sobre os centros decisórios. Em torno dessa questão também se manifestaria Golbery em documento datado de 1972, argumentando que

“[...] a centralização do poder político nas mãos do Executivo, as restrições ainda existentes para a atividade política e o excessivo controle do Estado sobre a economia são todos riscos calculados, aceitos conscientemente de forma a assegurar uma rápida decolagem do país [...]. Além disso, a coerção excessiva gera muito mais perigos e tensões [...]. Freqüentemente, como nesse caso, há um certo grau de incompatibilidade entre os diversos objetivos em conjunto. Essa incompatibilidade só pode ser contornada por uma manobra estratégica a ser planejada e executada numa sucessão de etapas" (Gaspari, 2003:198).

Nessa linha de raciocínio, apresentamos em trabalho anterior a idéia de que o projeto da distensão política foi uma estratégia articulada e amadurecida no decorrer do governo Médici, visando amenizar o grau de coerção, mas garantindo a continuidade do regime (Carvalho, 1989). É preciso reconhecer que a vontade de Médici foi determinante na escolha de Geisel para sucedê-lo na Presidência da República (D’Araújo e Castro, 1997:258). A iniciativa de Médici teve origem em janeiro de 1971, quando o presidente se reuniu com colaboradores próximos - entre eles o general João Batista Figueiredo, chefe do Gabinete Militar - e juntos aprovaram a candidatura de Geisel, um nome nacional que supostamente preservava a unidade militar. A partir dessa data até sua posse em janeiro de 1974, Geisel contou com um círculo íntimo de colaboradores que estabeleceu contatos com a área militar, o governo e setores do sistema político e da sociedade civil, formulando questões com foco nas mudanças que deveriam ser realizadas na organização do Estado. Enquanto o general Golbery entrava em contato com o empresariado, o general e o ministro de Exército 
Orlando Geisel e João Batista Figueiredo movimentavam-se dentro da burocracia militar do governo. Desse núcleo irradiador da proposta de distensão do regime também fizeram parte, entre outros, o marechal Cordeiro de Farias, ministro do Interior de Castelo, além de Heitor Ferreira de Aquino que era ligado por laços de amizade a Roberto Campos e foi assistente de Golbery no SNI durante o governo Castelo e assistente de Geisel na Petrobras (Gaspari, 2003).

Se no plano intragovernamental ocorreu uma articulação de apoio a Geisel, no plano institucional militar a Escola Superior de Guerra promoveu debates sobre o modelo político. Responsável pela preparação ideológica e técnica dos quadros militares e civis que assumiram posições dirigentes no Estado após 1964, a ESG tornou-se durante o governo Médici um centro de aferição e difusão de propostas no campo político-institucional. $\mathrm{O}$ foco recaiu sobre a questão da sobreposição da ordem jurídica institucional (AI-5) com relação à ordem constitucional, modificada e outorgada pela Emenda de outubro de 1969, quando foi ampliada no texto a noção de segurança nacional (Borges, 2003), refletindo a prioridade em fortalecer o aparato repressivo voltado para a defesa da segurança interna. Atores comprometidos com o regime - parlamentares, autoridades do Executivo e militares apresentaram as diferentes visões sobre a estratégia que pensavam adotar para institucionalizá-lo, dividindo-se entre a permanência e a extinção do AI-5. Embora restrito, o debate acabou ultrapassando os marcos da instituição militar e, em alguns momentos, ganhou repercussão na imprensa. Foi o caso, por exemplo, da palestra proferida na ESG pelo ministro da Justiça Alfredo Buzaid que defendeu uma posição de continuidade. Ele via como improvável a incorporação do AI-5 à Constituição e defendia a manutenção das duas ordens, a constitucional e a institucional. Na sua avaliação, a nação estava satisfeita com a conjuntura política e a revolução inaugurara uma Constituição que definia o regime democrático. Além de pedir a permanência das duas ordens jurídicas, Buzaid não fazia distinção entre a revolução como ideário e como processo, procurando sensibilizar as áreas políticas para a idéia de que uma "revolução que deseja alcançar seus supremos objetivos e desenvolver em toda a plenitude sua filosofia não deve promover a fixação de prazos e datas" ${ }^{\prime 2}$. No dia seguinte a esta declaração de Buzaid $^{13}$, também apresentada em uma palestra na ESG, o editorial do Jornal do Brasil, referindo-se a ela, lembraria 
"[...] que o movimento militar que pôs fim ao governo Goulart foi concebido e posto em prática de acordo com a tradição política brasileira, com o objetivo precípuo de restaurar a ordem no país, francamente ameaçada. Por esse motivo o movimento de março de 1964 teria contado com o apoio da opinião pública. Como decorrência, a palavra revolução teria uma inequívoca conotação de transitoriedade, o que implicava a idéia de instabilidade. $\mathrm{O}$ caminho da estabilidade seria o contrário do permanente estado revolucionário"14.

Questões como o tempo de intervenção das Forças Armadas, avaliação da conjuntura econômica, segurança do Estado, incluindo as atividades da esquerda armada, e modelo político ${ }^{15}$ adquiriram prioridade na agenda de discussão da ESG, contribuindo para a constituição de um campo de forças que não questionava o modelo burocrático-autoritário. A divergência central dava-se em torno das proposições de manter o regime fechado politicamente (linha dura) ou continuar com o regime, mas reduzir o coeficiente de arbítrio, pois "o arbítrio excessivo, já dizia Roberto Campos em 1972, passa a ser uma disfunção pela diminuição de insumos informativos e críticos" ${ }^{16}$. Para a linha de pensamento de Roberto Campos convergiam outras declarações surgidas no âmbito do sistema político e da sociedade civil, como a do senador Milton Campos que anteriormente já havia tornado público em discurso feito no Congresso Nacional uma posição divergente em relação à decretação do AI-5. O ex-ministro de Castelo lembrou os compromissos democráticos da revolução, sinalizando para o fato de que estaria havendo uma desvirtuação dos seus princípios originais. Ele propunha que se distinguisse a revolução de seu processo: "a revolução há de ser permanente como idéia e inspiração para que, com a colaboração do tempo possa produzir frutos. O processo revolucionário há de ser transitório e breve, porque sua duração tende à consagração do arbítrio"17. Além do governador da Bahia Luiz Viana Filho, chefe da Casa Civil no governo Castelo, que pregava a "retomada democrática"18 e do general Rodrigo Otávio, então comandante da ESG, que propunha conciliar a condição de segurança com a redução do arbítrio, soma-se ao discurso que demandava a redução da coerção estatal o pronunciamento do marechal Cordeiro de Farias, um dos líderes do movimento de 1964 e ministro do Interior de Castelo. Em palestra na ESG em março de 1970 ele havia feito críticas ao desfecho de 1968 e afirmara que o "AI-5 afastava da Revolução 
uma grande e numerosa classe que pelo menos moralmente ficou sem situação para defendê-la".

As declarações dos protagonistas do autoritarismo que se tornaram de domínio público, somadas à articulação do grupo intragovernamental de apoio à candidatura de Geisel são claros sinais de que a dinâmica do processo político durante o governo Médici foi marcada por disputas em torno de posições na corrida sucessória e por intensas polêmicas sobre o tipo de modelo político a ser institucionalizado. Mostram também que alguns segmentos próximos aos centros de poder estavam defendendo uma clara estratégia de resistência aos rumos que o Estado tomara após a decretação do AI-5. Ao questionar a manutenção de um tipo de autoritarismo mais dependente do apoio das Forças Armadas, que desacreditava por completo as tradicionais mediações institucionais, a corrente mais moderada acabou galvanizando opiniões que ultrapassavam as fronteiras do aparelho de Estado. Alguns representantes da grande imprensa liberal, que antes haviam apoiado o golpe em 1964, pronunciaram-se sobre a evolução do regime durante o governo Médici. Apesar da forte censura a que estavam submetidos, construíram um discurso de aproximação com os grupos favoráveis à diminuição do grau de coerção estatal. Foi o caso do Jornal do Brasil que, embora não contestasse a ordem instituída, adotou uma linha editorial que procurava ampliar o exíguo campo de crítica a um regime que perdera as referências legais. O jornal adotou uma estratégia discursiva de resistência ao tipo de autoritarismo inaugurado após a decretação do AI-5, questionando a proposição de que o Estado representava a totalidade da opinião pública. Freqüentemente exaltava o compromisso original dos dirigentes militares, argumentando que a defesa do Estado de Direito teria permitido o acordo entre as Forças Armadas e setores da sociedade na deposição de Goulart em 1964. Nos textos do Jornal do Brasil sobressaía a idéia de que o caminho para se encontrar a estabilidade política exigia a garantia dos direitos dos indivíduos e o reconhecimento das tradicionais instituições representativas da opinião pública contempladas na cultura liberal-democrática. Enfim, o jornal que utilizamos como uma das fontes do trabalho citado acima não apenas espelhou uma luta interna que se travava nos bastidores do Estado entre as diversas tendências em disputa pela sua direção. Ele acabou por ser um campo produtor de significados correspondentes às demandas dos atores que viam na diminuição do grau de autoritarismo sobre a imprensa, os partidos, as eleições e o Legislativo o primeiro passo para cami- 
nhar no sentido de um Estado mais controlado pela sociedade, prescindindo, assim, da intervenção militar na vida política.

Formulada em um contexto de crescimento econômico do país e de maior retração das instituições da sociedade civil diante do Estado, a estratégia de distensão explica-se, sobretudo, pelos antecedentes ideológicos da cultura política e dos diversos atores ${ }^{19}$, cujos componentes pluralistas se manifestaram até mesmo no discurso adotado pelos dirigentes militares comprometidos com a idéia de uma democracia forte. Esta deveria ser instrumentalizada com as necessárias salvaguardas de defesa do Estado, afinal não se poderia esquecer os riscos e desafios enfrentados no último período democrático durante o governo Goulart. Todavia permanecia o compromisso de se construir um regime que mantivesse pontos de contato com os princípios liberais da ordem político-burguesa. Nesse sentido, acreditamos que os dirigentes militares perceberam limitações no tipo de autoritarismo instituído após a crise de 1968, principalmente os integrantes do grupo que assumiu maiores responsabilidades no governo Castelo, do qual fizeram parte Geisel e Golbery. Identificados como a corrente mais moderada, eles mostraram intenções de estruturar um tipo de Estado que buscasse algum fundamento de sua legitimidade também no desempenho eleitoral. Em outras palavras, os dirigentes foram influenciados pelo pensamento de que deveriam manter os mecanismos eleitorais e partidários em torno dos quais os regimes políticos no mundo ocidental democrático comumente adquirem a base de sua legitimidade. Com esse objetivo deve ser compreendida a ascensão de Geisel à presidência que representaria a retomada, em linhas gerais, do projeto castelista ${ }^{20}$ idealizado no primeiro governo.

Nos primeiros movimentos em direção à liberalização é difícil imaginar os militares envolvidos pela idéia de retirar lenta e gradualmente a instituição do poder. Devemos lembrar que em nenhum momento após ter assumido a presidência, Geisel acenou com a possibilidade de eleições livres e diretas para a escolha do próximo presidente, tal como exigia a oposição democrática. Ele deixou bem claro que os instrumentos de exceção permaneceriam "até que sejam superados pela imaginação criadora, capaz de instituir, quando for oportuno, salvaguardas eficazes dentro do contexto constitucional"21. O objetivo que se esboçava, portanto, continuava a ser o da institucionalização de um regime que anunciava medidas liberalizantes, mas as condicionava à consolidação do projeto autoritário ${ }^{22}$. A eliminação dos mecanis- 
mos excessivamente coercitivos não deveria colocar em risco o controle dos cargos executivos nem tampouco a maioria governamental no Congresso para aprovar a legislação necessária às reformas. Nesse sentido, os estrategistas governamentais, contando com os indicadores ainda relativamente favoráveis na economia e com o suposto apoio social herdado do "milagre", esperavam repetir a vitória obtida pela Arena nas eleições municipais de 1970, evidentemente sem os efeitos negativos provocados pela intensa repressão da época. Se as eleições parlamentares marcadas para novembro de 1974, entretanto, transcorressem em um ambiente de liberdade, isso significaria a ampliação da legitimidade eleitoral tão almejada desde o governo Castelo. O diagnóstico otimista, conforme as previsões registradas nos documentos do SNI (Castro, 2002:44), foi todavia ultrapassado pelo realismo da luta política, pois as mudanças beneficiaram a oposição institucional representada pelo Movimento Democrático Brasileiro MDB. Aproveitando a oportunidade de maior liberdade para tecer alianças e difundir idéias pelos meios de comunicação, o partido ampliou o potencial de atuação e obteve uma expressiva vitória após uma campanha de denúncias contra o regime focadas em três temas: a violência contra os direitos humanos, a concentração de renda no país e a desnacionalização da economia. O MDB conquistou mais de um terço do Congresso, levando o governo a perder a maioria necessária para emendar a Constituição. Em função de seu sucesso nas eleições legislativas de 1974, o MDB consagrou-se como porta-voz legítimo da oposição democrática (Kinzo,1994).

A liberalização implicou riscos, pois as garantias dadas pelos dirigentes de que se iniciava um novo tempo de maior segurança com relação aos direitos dos indivíduos e dos grupos provocaram repercussões no plano social, propiciando o surgimento de uma expectativa positiva com as formas de comportamento oposicionista dos atores. Até mesmo os grupos da esquerda armada, após serem desestruturados pela repressão e se desvencilharem da estratégia de luta revolucionária, passaram a valorizar a conquista do poder pela via institucional, reforçando a representatividade do MDB. A partir de então o regime passou a viver cada vez mais os efeitos da ausência crônica de legitimidade com relação às suas regras de procedimentos. Quanto mais adotava as medidas de cunho liberal para ampliar sua base política e social, mais ilegítimo tornava-se aos olhos da população. Nessas circunstâncias de retomada da politização da sociedade, envolvendo 
maior liberdade de crítica por parte da imprensa e o gradual incremento da ativação popular, as variações arbitrárias do poder governamental visaram impedir a perda de controle sobre a agenda política, de modo a determinar o ritmo e o alcance das mudanças. Assim deve ser compreendida a instituição da Lei Falcão em 1976, quando se avaliou que os resultados das eleições de novembro de 1974 comprometeriam nos próximos pleitos o controle do governo sobre o processo legislativo. Com a proibição da propaganda eleitoral no rádio e na televisão, a população não teve mais acesso às críticas da oposição sobre as políticas governamentais. Para garantir a base parlamentar necessária à continuidade da estratégia da liberalização outorgada, o governo também investiu contra o Senado e a Câmara. Em abril de 1977, o presidente Geisel colocou o Congresso em recesso e mudou as regras do jogo, aprovando um conjunto de medidas que ficou conhecido como Pacote de Abril ${ }^{23}$.

Ao término do governo Geisel a ambigüidade do regime se mantinha. O AI-5 foi extinto após ter sido utilizado para cassar mandatos de deputados estaduais e federais e colocar em recesso o Congresso para impor as reformas constitucionais em abril de 1977. Suspenso desde dezembro de 1968, o habeas corpus para detidos por motivos políticos fora restaurado. A censura à imprensa havia sido suspensa e com a revogação dos decretos de banimento grande parte dos exilados políticos voltava ao Brasil, indicando que o país se preparava para novos tempos políticos. De fato a liberalização avançara, embora o Pacote de Reformas de 1978, introduzido sob a forma da Emenda Constitucional $\mathrm{n}^{\circ} 11$, estabelecesse novos controles por meio de medidas denominadas "salvaguardas de emergências" 24. Além disso, deve-se destacar que o vasto aparato de segurança se mantinha intacto. Eram de domínio público as denúncias contra as forças de segurança responsabilizando-as por prisões, torturas e mortes de opositores. Portanto, o desafio do governo Geisel não se resumiu em desmantelar e renovar a estrutura legal autoritária, ao mesmo tempo que manipulava o sistema eleitoral para impedir a oposição de conquistar o poder no âmbito das próprias regras do regime. Também foi preciso recuperar a autoridade presidencial sobre as ações dos órgãos de repressão controlados pela linha dura militar, tarefa que contou com os recursos do $\mathrm{SNI}^{25}$ sob a chefia do general Figueiredo (Castro, 2002:53-55), o indicado posteriormente por Geisel para ocupar a presidência da República $^{26}$. Uma vez que o governo precisava do apoio das Forças Arma- 
das, foi preciso combinar o enfrentamento com a negociação em relação aos setores internos ao Estado que reagiam ostensivamente às mudanças liberalizantes ${ }^{27}$.

A proposta de liberalização acionou reações até porque significava a perspectiva de deslocamento de grupos encastelados no aparelho de Estado que, inevitavelmente, perderiam posições de poder conquistadas após a radicalização das ações repressivas empreendidas após 1968. Considerando também que houve um envolvimento direto dos militares nas tarefas repressivas, foi equivalente o medo de que após a retirada das Forças Armadas do poder tais responsabilidades pudessem ser apuradas judicialmente. Assim, o receio de um revanchismo constituiu-se em um forte argumento para os grupos de sustentação do regime que desejavam a reversão da transição. Dispostos a manter o Estado-policial que tantos custos políticos causou à instituição militar e ao regime como um todo, setores da linha dura insistiram na intenção de afastar da convivência social qualquer vestígio de normalização das instituições representativas. Todavia, a estratégia de Geisel de contenção dos bolsões radicais mas sinceros, como eram chamados pelos dirigentes militares, não se propunha a anular o desempenho das funções repressivas do Estado. A intenção era a de recuperar um clima político que evocasse o Estado de Direito, e, para isso, tornava-se necessário obter um controle mais rigoroso sobre os aparatos de segurança que desafiavam qualquer limite legal instituído. Nesse sentido, deve ser compreendida a "Diretriz de atuação do CIE" baixada em 1974, subordinando as operações do Centro a um entendimento com os comandantes dos quatro exércitos (Gaspari, 2003:403). Portanto, sem questionar a manutenção dos aparelhos de espionagem, os dirigentes preocuparam-se também com a retomada de certos princípios liberais que encontravam obstáculos para firmarem sua credibilidade tendo em vista a autonomia adquirida por esses órgãos da polícia política. A presença discreta e regulada desses serviços secretos diminuiria o desgaste dos militares enquanto instituição comprometida com a repressão, ao mesmo tempo que manteria seu potencial de dissuasão para com aqueles que contestassem o poder governamental.

De acordo com essa abordagem, as revelações de Geisel apoiando a tortura e o extermínio de militantes da esquerda podem ser mais bem avaliadas desde que possamos esclarecer até que ponto as ações do aparelho repressivo controlado pela linha dura, em que pesem a sua 
autonomia, respondiam às metas traçadas pelas altas figuras do Estado, não desafiando a autoridade do presidente, nem tampouco desgastando a imagem das Forças Armadas. Se não devemos diluir completamente as fronteiras entre essas duas correntes que tinham influência na direção do Estado, é preciso repensar as relações entre os grupos levando em conta que a longa duração do regime exige a ênfase na complementaridade dos papéis por eles desempenhados. Poderíamos supor que as prisões, torturas e mortes de dirigentes do PCB ocorridas entre 1973 e 1976, partido ao qual os dirigentes militares atribuíam influência na vitória do MDB nas eleições em novembro de 1974, fizeram parte de uma longa e planejada ação, contando com anuência da cúpula do poder ${ }^{28}$. Nessa linha de interpretação se coloca também a ação repressiva que culminou no Massacre da Lapa ${ }^{29}$, com mortes de dirigentes do PC do B em dezembro de 1976, quando o II Exército estava sob o comando do general Dilermando Gomes Monteiro, considerado moderado e íntimo colaborador de Geisel (Skidmore, 1988:348). O mesmo raciocínio não poderia ser aplicado às mortes do jornalista Vladimir Herzog em outubro de 1975 e do metalúrgico sindicalista Manoel Fiel Filho em janeiro de 1976, compreendidas mais como provocações do aparato repressivo ${ }^{30}$, ficando a responsabilidade restrita aos oficiais do II Exército, sob o comando do general Ednardo d'Ávila. Outro famoso caso de provocação teria sido a explosão da bomba no Riocentro em 30 de abril de 1981, durante show comemorativo do Dia do Trabalho, quando morreu no local um sargento e ficou ferido um capitão, dois militares do Exército pertencentes ao DOI-CODI. Vale lembrar que, exceto os dois primeiros episódios, os outros resultaram em crises na cúpula militar, com a demissão do comandante do II Exército Ednardo d'Ávila pelo presidente Geisel após a morte do metalúrgico. No caso do Riocentro ocorrido no governo Figueiredo, o general Golbery renunciou ao cargo de chefe do Gabinete Civil da presidência por discordar dos rumos tomados pelo inquérito realizado pelo Exército, que encobriu os responsáveis pela ação terrorista.

Embora fosse verdadeiro o empenho de Geisel e Figueiredo para controlar as ações dos órgãos de segurança do aparato repressivo, os presidentes não se comprometeram em desmontá-lo, mesmo recebendo das oposições demonstrações de apoio manifestadas nas condenações a qualquer ato de violência e, em particular, aos atos de terrorismo praticados pela linha dura. Apesar da existência de um campo co- 
mum de interesses com a oposição parlamentar, que cooperava com o jogo político no sentido de evitar o recrudescimento autoritário, em nenhum momento os dois últimos governos militares prescindiram da Lei de Segurança Nacional, considerada uma "salvaguarda necessária a uma "democracia forte" ${ }^{31}$, em oposição a tradicional democracia liberal" (Stepan, 1986:64). Vale lembrar que durante a greve dos metalúrgicos na região do ABC em São Paulo em 1980, o sindicato sofreu intervenção do Ministério do Trabalho, sendo Lula e os dirigentes sindicalistas destituídos dos seus cargos e presos em uma ação conjunta envolvendo tropas de choque e oficiais das forças de segurança do Exército, o conhecido DOI-CODI. Lula e mais dez líderes sindicais foram condenados por um tribunal militar em 1981 acusados de violar a Lei de Segurança Nacional (Skidmore, 1988:435). O movimento sindical na região do $\mathrm{ABC}$ em São Paulo serve de exemplo de que a luta dos trabalhadores por melhores salários e pelo direito de greve ocorria sob um clima de medo de uma regressão repressiva. A negociação com base na intimidação e a repressão aberta faziam parte das práticas da elite militar dirigente e constituíam as duas faces do Estado autoritário. Portanto, desde que devidamente enquadradas dentro dos objetivos do projeto de distensão / abertura, as forças de segurança continuaram a ser peças fundamentais na defesa do Estado que carecia de legitimidade democrática. Elas constituíam um dos eixos de apoio do esquema de poder militar, que sempre se utilizou de um vasto arsenal de leis e de práticas autoritárias para restringir a participação popular e impedir a alternância no poder. Uma vez que a tradicional política com base na argumentação racional e pública foi substituída pela cultura de guerra, os órgãos de segurança permaneceram até o último governo prontos para agir conforme a natureza do regime, procurando o inimigo interno, intimidando as oposições e praticando a violência contra os mais elementares direitos humanos.

Os sinais de que os dirigentes pretendiam chegar a uma "fórmula política pós-autoritária não democrática" (O’Donnell e Schmitter, 1988:52) ficam evidentes se colocarmos em foco a lei da anistia aprovada pelo Congresso em 1979 no governo Figueiredo, antecedendo a reformulação partidária idealizada por Golbery. A anistia foi debatida da perspectiva da oposição democrática, com apoio de entidades da sociedade civil, que a defendia ampla, geral e irrestrita, implicando a revisão das medidas punitivas que afetaram desde 1964 o meio 
civil e militar, bem como a cobrança judicial dos responsáveis por atrocidades repressivas tais como tortura e assassinatos de presos políticos. Da ótica dos dirigentes, principalmente do aparelho responsável pela dura repressão empreendida, a proposta de anistia anunciada pelos setores da oposição foi encarada como um ato de revanchismo. Acabou prevalecendo a proposta negociada com a oposição parlamentar de uma anistia recíproca que enfatizava a fórmula do esquecimento dos atos repressivos praticados no passado. Ao não permitir qualquer revisão judicial das suas ações, o aparelho militar protegeu sua autonomia, reforçando o sentimento de impunidade e de imunidade das Forças Armadas. A sociedade, por sua vez, deixou de conhecer os agentes diretamente implicados nas atrocidades cometidas e as engrenagens dos aparatos repressivos, fundamentais na sustentação do regime autoritário. Como não foram cobradas responsabilidades pelos atos repressivos, a instituição militar não foi colocada no centro de um amplo debate nacional sobre os papéis que vinha cumprindo na esfera política e a opinião pública não colocou em discussão os valores éticos necessários para a construção de uma autêntica democracia.

É verdade que no final do governo Figueiredo, depois de vinte anos de autoritarismo, as pressões para ampliar a democratização intensificaram-se, sobretudo com as mobilizações populares a favor das " $\mathrm{Di}$ retas Já!". Lideradas pelos partidos da oposição (PMDB, PDT, PT e outros) e com apoio de instituições da sociedade civil como a Ordem dos Advogados do Brasil - OAB, a Associação Brasileira de Imprensa - ABI e a Conferência Nacional dos Bispos do Brasil - CNBB, as manifestações, todavia, não impediram a derrota no Congresso em abril de 1984 da emenda do deputado Dante de Oliveira do PMDB. Cabe lembrar que a votação da emenda das diretas ocorreu sob um clima ameaçador em virtude do estado de emergência decretado em Brasília, executado pelo general Newton Cruz, comandante militar do Planalto e ex-chefe da agência do SNI da capital. Com a garantia de que a transição se realizaria nos moldes da institucionalidade vigente, parecia certa a vitória do candidato presidencial do regime, em função da maioria casuística obtida pelo partido do governo no Colégio Eleitoral. Todavia, acirraram-se as divergências internas no partido do governo tornando impossível a definição de um candidato à presidência da República. Nesse cenário foi criada a Aliança Democrática, nascida de um ambiente de conciliação e de um pacto articulado entre setores 
da oposição liberal (PMDB) e dissidentes do regime (PFL). Após a eleição de Tancredo Neves pelo Colégio Eleitoral, e, em seguida, a sua morte, o país viu o comando da transição negociada em direção à democracia ser assumido pelo vice-presidente José Sarney, político da antiga UDN, da ARENA e do PDS, identificado como um civil de confiança dos militares. Herdeiro de uma grave crise econômica e de uma dívida social sem precedentes na história da República, o governo Sarney permitiu que os militares continuassem a encontrar condições favoráveis para reproduzir suas intenções de vigília sobre o sistema político, embora tivessem deixado de intervir diretamente na direção do Estado, como o fizeram de 1964 a 1985.

Sob o comando de Sarney, o governo civil incorporou as marcas de uma história não terminada, deixando a mostra o quanto era forte o componente militar nas estruturas do regime de transição. As Forças Armadas brasileiras não foram obrigadas a aceitar um papel radicalmente diferente daquele assumido na fase autoritária, quando elas tiveram maiores responsabilidades na implementação de políticas públicas e no condicionamento da postura dos demais atores. Apesar de o sistema político ter sofrido transformações de cunho liberal-democrático, com a aprovação do Congresso de leis restabelecendo as eleições diretas para a presidência da República, concedendo o direito de voto aos analfabetos e a liberdade para a organização dos partidos, o país ainda não havia conseguido produzir uma força capaz de conter e disciplinar a vontade militar interventora. Estudiosos já haviam alertado para o fato de que a desmilitarização não constituía um problema que dizia respeito tão somente aos militares (O'Donnell e Schmitter, 1988:58). Notava-se na Nova República omissões das instituições políticas, particularmente dos partidos e do Congresso quanto às responsabilidades na elaboração de projetos para controlar o poder militar (Carvalho, 1987). Era o caso do Conselho de Segurança Nacional, cujos poderes estabelecidos pela Constituição de 1967 o transformaram em órgão de extrema importância pela responsabilidade em definir e executar a política de segurança interna do país. Como órgão da presidência da República, o Conselho de Segurança Nacional se militarizara, "em razão da integração de suas funções, finalidades e estruturas com a intervenção militar" (Oliveira, 1987a:160). Entre outros exemplos que evidenciavam a falta de agressividade construtiva, para não falar da ausência de ousadia por parte das forças civis em querer regular a ação militar, desta- 
cava-se o Serviço Nacional de Informações -SNI, que ainda não havia sido formalmente mudado. Este órgão de inteligência, que acabaria saindo intacto do processo constituinte de 1988, tornou-se um exemplo de preservação das estruturas autoritárias pelo qual a instituição militar manifestava os interesses das corporações. Ele prestou relevantes serviços ao governo Sarney no campo da avaliação conjuntural, monitorando não só a atuação dos setores de oposição de esquerda liderados pelo Partido dos Trabalhadores, bem como as articulações entre as demais forças políticas. O ministro chefe do SNI na época, o general Ivan de Souza Mendes, marcou presença no governo por endurecer as negociações com líderes sindicalistas, reduzindo o espaço de negociação do então ministro do Trabalho Almir Pazzianotto. A manutenção das estruturas repressivas controladas pelos militares, lembrando ainda a imagem de uma instituição toda-poderosa com força impositiva, foi um fator inibidor da prática democrática. Eis por que para o primeiro governo da Nova República foi cunhado o termo democracia tutelada, sinalizando para o fato de que, apesar dos progressos feitos em direção da civilização das decisões governamentais, o país ainda guardava um elevado nível de militarização da vida política ${ }^{32}$. Além de a cúpula militar opinar sobre inúmeras questões fora das atribuições específicas militares tais como greves, reforma agrária e tempo de mandato do presidente Sarney, cabe observar que o Congresso Constituinte de 1988, no que trata das funções das Forças Armadas, não modificou na essência as antigas cláusulas constitucionais, cabendo-lhes a garantia da lei, da ordem e também a dos poderes constitucionais. Uma vez que às Forças Armadas, segundo a Constituição, foi atribuído o papel de zelar pela segurança interna e externa, elas continuaram a manter as condições para julgar no futuro se devem ou não intervir em situações de crise, como sempre fizeram desde a instituição da República.

Procurei defender neste artigo a idéia de que a proposta de liberalização do regime estava presente no universo ideológico do autoritarismo e sua implementação a partir de 1974 deve ser entendida como a resultante do conflito interno de um sistema de poder orientado pela concepção de que a imposição de uma maior coerção garantiria as condições para a expansão econômica capitalista. Baseados na Doutrina de Segurança Nacional, na teoria do "inimigo interno" e na existência de uma guerra revolucionária comunista, os dirigentes criaram um Estado de controle repressivo que no decorrer dos sucessivos 
governos militares estrangulou as antigas estruturas institucionais representativas herdadas do modelo liberal democrático. Dessa ótica, a retomada da proposta de liberalização no âmbito da liderança militar e civil autoritária, ainda durante o governo Médici, vai ao encontro da linha de abordagem que enfatiza a autonomia do núcleo dirigente e sua capacidade de assumir a iniciativa das mudanças, manifestada nas articulações para impulsionar a candidatura de Geisel e na consciência de que, para além da eficácia econômica conseguida nos início dos anos 70, emergia o problema da legitimidade ${ }^{33}$ das regras políticas.

Assim, a revitalização dos mecanismos representativos clássicos, eleitorais e partidários não refletiu modificações no equilíbrio de forças entre a oposição e os protagonistas do regime, mas teve sua origem na luta intra-grupos dirigentes ocorrida no período mais repressivo do ciclo militar inaugurado em 1964. Aceitar, todavia, que a liberalização promovida pelos dirigentes militares se enquadrava dentro de uma perspectiva de ampliar o apoio político e social e que ela foi originalmente desencadeada em função das dificuldades do regime em resolver suas contradições internas (Martins, 1988) não significa negar a presença do fator pressão por parte dos atores oposicionistas do sistema político e da sociedade civil. Mas sim dimensionar seu tempo de entrada no cenário político e sua influência sobre o ritmo e o alcance das medidas implementadas após 1974. Somente após o anúncio da liberalização feito pelo presidente Geisel, as lideranças da oposição e as instituições da sociedade civil assumiram diante do Estado uma postura mais ativa, no sentido de exercer a crítica ao regime e incentivar a participação popular. A debilidade das forças comprometidas com a democracia ${ }^{34}$ contribuiu para uma transição que se estendeu por um longo tempo, ficou sob relativo controle da cúpula militar e desaguou em um compromisso político conservador, garantindo a presença das elites dissidentes do regime autoritário no comando do primeiro governo civil após as Forças Armadas se retirarem do poder, quando teve início a Nova República.

Nesse sentido, a distensão/abertura distinguia-se do projeto de democratização aspirado por diversos setores da oposição. A implementação das medidas liberalizantes iniciadas por Geisel estava condicionava à institucionalização de um tipo de regime pós-autoritário com restrições democráticas, o que significa que no projeto de distensão/abertura, a retirada das Forças Armadas da direção do Estado 
implicava mais do que a sua substituição por um esquema civil de confiança baseado no partido do governo, de modo a preservar os interesses institucionais das corporações. Como integrantes do aparelho de Estado, os militares deveriam continuar a exercer sua influência sobre as questões em discussão pelos atores do sistema político e da sociedade civil, a fim de garantir a institucionalização de um poder político voltado, sobretudo, para moderar a participação popular tanto na constituição de governos quanto na formação das suas decisões.

(Recebido para publicação em março de 2004)

(Versão definitiva em dezembro de 2004)

\section{NOTAS}

1. O livro do jornalista Elio Gaspari A Ditadura Derrotada também contém importantes informações sobre a natureza repressiva do regime autoritário. Com base em gravações e documentos pertencentes aos arquivos dos protagonistas do regime, $\mathrm{o}$ jornalista revela uma conversa em que o presidente Ernesto Geisel manifestou ao ministro do Exército, o general Dale Coutinho, sua aprovação à eliminação de militantes comunistas (Gaspari, 2003:324). Segundo Geisel, Dale Coutinho era seu “amigo e conhecido de longa data" (D'Araújo e Castro, 1997:268).

2. Após as eleições para governadores em outubro 1965, o governo de Castelo, do qual o general Geisel era chefe da Casa Militar, enfrentou pressões das bases militares. A oposição havia obtido no pleito a vitória em Minas Gerais e Guanabara, estados governados por líderes da UDN que tiveram presença destacada na conspiração contra Goulart. Foi a primeira crise militar mais séria que resultou no AI-2 com a extinção dos antigos partidos (PSD, PTB, UDN e outros), a instituição do bipartidarismo (MDB e ARENA) e as eleições indiretas para presidente, vice-presidente, governador e vice-governador. O desfecho do episódio barrou o projeto do então chefe do SNI, o general Golbery, que havia tentado postergar as eleições para governadores de outubro de 1965 e articulava a reeleição de Castelo para que seu governo se estendesse até março de 1969 (Gaspari, 2003:171). Nesse sentido, os resultados eleitorais de 1965 não favoráveis ao governo apontaram também para uma nova correlação de forças entre os grupos dirigentes. O ministro da Guerra Costa e Silva assumiu a partir daí uma postura mais aberta de candidato à presidência e passou a galvanizar apoio dos oficiais de linha dura. Embora tentasse promover um candidato civil da área política de sua confiança, Castelo acabou aceitando, em nome da unidade militar, a escolha de Costa e Silva, homologado pela Arena e pos- 


\section{Aloysio Carvalho}

teriormente eleito pelo Congresso em outubro de 1966 (D'Araújo e Castro, 1997:189 e 196).

3. Nesse aspecto, a Doutrina de Segurança Nacional teria resgatado elementos do moderno pensamento militar formulado pelo general Góis Monteiro que considerava a "defesa nacional fator e resultado de uma política de desenvolvimento nacional que, para ser eficaz, supõe como condição uma estratégia global de rígida contenção das forças políticas em luta e de disciplina social". Adotei a posição de Edmundo Campos Coelho (1976:114) que enfatiza linhas de continuidade na construção do pensamento militar pós-64. Segundo o autor, a fórmula Segurança e Desenvolvimento seria em essência uma visão atualizada da idéia desenvolvida por Góis Monteiro, ao formular uma doutrina para o Exército durante o Estado Novo.

4. Malan vê os civis capazes de assumir o poder (Jornal do Brasil (15/12/1971, p. 3).

5. Comentário feito pelo deputado Tales Ramalho (MDB-PE). “Tarso admite retorno rápido à normalidade" (Jornal do Brasil, 5/1/1972, p. 3).

6. O trabalho de Fleischer mostra como a manipulação casuística no plano político eleitoral tem tradição no país. Entretanto, a manipulação autoritária pós-64 foi levada ao extremo. O autor coloca em dúvida a eficiência das manipulações político-eleitorais praticadas no período militar. Além de afirmar que os "engenheiros não compreendiam as suas conseqüências", ele argumenta que as "mudanças se tornaram uma faca de dois gumes, dada a combinação de um sistema eleitoral fraco e partidos não muito institucionalizados com um eleitorado cada vez menos manipulável" (Fleischer, 1994).

7. Na linha de análise que enfatiza o estudo dos textos constitucionais, Pessanha esclarece como foram operadas as restrições impostas pelo regime autoritário ao exercício do Poder Legislativo. A Carta de 1967 manteve as restrições à iniciativa legal do Poder Legislativo, criou duas modalidades de delegação legislativa e constitucionalizou o decreto-lei (Pessanha, 2002:166-171).

8. Concordo que não havia "planos de governo detalhadamente estabelecidos", a não ser algumas "diretrizes de saneamento econômico-financeiro traçadas por alguns ipesianos" (Fico, 2004:74). Todavia, é possível imaginar que os dirigentes mais voltados para a questão da institucionalização política estivessem desde a tomada do poder em 1964 amadurecendo algumas reformas nesse campo, considerando os graves conflitos no governo Goulart. Castelo, segundo Geisel, acreditava em uma "nova Constituição, com o regime de dois partidos e talvez com a instituição da eleição indireta" (D'Araújo e Castro, 1997:200), regras que foram introduzidas com o $\mathrm{AI}-2$, juntamente com as medidas repressivas exigidas pela linha dura para retomar a "operação limpeza".

9. Em que pese a relativa estabilização do crescimento dos preços entre 1964 e 1972, os indicadores evidenciam a deterioração na distribuição de rendas, expondo a perversidade do modelo econômico. Entre 1960 e 1970, a parcela de renda apropriada pelos $40 \%$ mais pobres da população declinou de $15,8 \%$ para $13,3 \%$, alcançando 10,4\% em 1980 e 9,9\% em 1990 (Cysne, 1994).

10. Poder econômico destrói a liberdade, diz Mem de Sá (Jornal do Brasil, 22/12/1970, p. 4).

11. Doutrina perigosa (Jornal do Brasil, 23/12/1970, p. 6). 
12. A declaração do ministro Buzaid respondia a uma pergunta formulada durante conferência na ESG por um estagiário desta instituição sobre a institucionalização da revolução, quando o tema do marxismo e cristianismo foi abordado (cf. Jornal do Brasil, 4/7/1970).

13. Hélgio Trindade vê em Buzaid um dos representantes da corrente integralista que teria compartilhado o poder no governo Médici. $\mathrm{O}$ autor detecta a existência de uma nova tentação fascista, possibilitada pela formação de uma atmosfera favorável à ação de radicais de direita. Sua origem estaria no vácuo político formado após a rápida queda de Goulart e nas disputas internas pelo poder pós-64 entre os moderados da "Sorbonne" representados pelo presidente Castelo e a "linha dura" comandada pelo ministro da Guerra Costa e Silva, que acabou liberando o avanço das forças repressivas após o AI-5. A tentação fascista representaria a ruptura com a base civil udenista ocorrida após a doença de Costa e Silva, quando se decidiu que uma junta militar assumiria o poder (Trindade, 1994).

14. Transitório e permanente (Jornal do Brasil, 4/7/1970, p. 6).

15. Para o acompanhamento dessas questões e do debate promovido pela ESG que suponho ter existido durante o governo Médici, ver Carvalho (1989).

16. Citação feita pelo deputado da Arena Etelvino Lins Albuquerque, que resgatou o pensamento de Roberto Campos (ver "Etelvino acha clima propício para conciliação", Jornal do Brasil, 17/1/1972, p. 3).

17. Diário do Congresso Nacional, nov.1969, sábado, 8-0271. Extraído do Jornal do Brasil, 1972.

18. Luiz Viana quer líderes na luta pela democracia (Jornal do Brasil, 13/1/1971, p.3).

19. Ao discutir a liberalização, Bolivar Lamounier (1988) enfatiza a força da tradição liberal e pluralista do sistema político brasileiro.

20. Ao esclarecer o processo sucessório no governo Médici e o surgimento de sua candidatura, Geisel reconhece a existência de uma corrente castelista da qual fariam parte Golbery, Luiz Viana e Roberto Campos (D'Araújo e Castro, 1994:257).

21. Trecho do discurso de Geisel pronunciado na abertura da primeira reunião de seu Ministério (Cruz e Martins, 1983:46).

22. Na análise da documentação do Arquivo Geisel sobre o Ministério da Justiça, cujo titular da pasta era Armando Falcão, D'Araújo nota que, antes da posse, havia a "nítida preocupação do futuro ministro em desenvolver ações que permitissem o aprimoramento da 'Revolução' e que reforçassem os instrumentos para o controle do governo sobre a oposição". "O ministério após a posse de Geisel assumiu uma linha de ação no sentido de consolidar a 'Revolução'”; para tanto deveria promover a institucionalização da "Revolução através de uma reforma da Constituição que produzisse um modelo político brasileiro". Isso significava a manutenção e o aprimoramento do bipartidarismo, o fortalecimento da Arena e a instrução de seus quadros para serem mais agressivos no Congresso na defesa do governo (D'Araújo, 2002:26 e 35).

23. No plano eleitoral, a Emenda no 8 estipulava que um terço do Senado e os governadores estaduais seriam eleitos pela via indireta. Foram também modificados os critérios que regulamentavam o número de deputados federais e a escolha dos delegados municipais junto ao Colégio eleitoral, reduzindo o peso das regiões industri- 


\section{Aloysio Carvalho}

alizadas. As restrições à propaganda adotadas para as eleições municipais foram estendidas para todas as eleições que envolvessem o voto popular (Alves 1989:194).

24. Com as salvaguardas que complementavam os dispositivos constitucionais para a declaração de estado de sítio, o Executivo adquiria poderes extraordinários em caso de guerra externa, de ameaça à existência do Estado, ou em casos de sublevação interna (Alves, 1989:218).

25. As a preciações do SNI manifestadas nos documentos pertencentes ao Arquivo Geisel indicam o esforço desse órgão no sentido de controlar os métodos repressivos que causavam desgastes políticos para o regime naquela conjuntura de liberalização política (Castro, 2002).

26. Há uma correspondência entre o fortalecimento do SNI, que durante o governo Figueiredo "transformou-se numa espécie de quarta força armada, tamanho era seu poderio", e a fragilização nesta fase do Sistema DOI-CODI, considerado o principal obstáculo ao projeto de abertura política (Fico, 2003:200).

27. Segundo Geisel, "um dos fatores que é preciso levar em conta é que eu (Geisel) não podia ficar com as Forças Armadas e principalmente o Exército contra mim". O combate à subversão era um dentre os muitos temas que eu tinha que atender. Era um dos problemas. Eu também não podia ser radicalmente contrário ao combate. Podia ser contrário aos métodos, aos procedimentos, à maneira de combater, e sobre isso eu muito conversava, e muitas vezes procurava convencer" (D'Araújo e Castro, 1997:379).

28. Geisel reconhece que durante o seu governo e todo o período militar "sempre se procurou acompanhar e conhecer o que o partido (Comunista) fazia, qual era a sua ação, como ele se conduzia, o que estava produzindo, qual era o grau de periculosidade [...]. No fim do governo, o Dilermando, já no comando do II Exército, atuou em São Paulo sobre uma grande reunião dos chefes comunistas. [...] Fizemos tudo para evitar um recrudescimento das ações comunistas. Porque houve época em que eles matavam, roubavam, faziam o diabo" (D'Araújo e Castro, 1997:366).

29. Os preparativos dessa ação repressiva, segundo D'Araújo, estão parcialmente registrados no Arquivo Geisel referente ao Ministério da Justiça ( 2002:31).

30. Perguntado se as mortes de Herzog e Fiel Filho teriam sido um acidente de trabalho da repressão ou uma provocação intencional de grupos interessados em desestabilizar o processo de abertura, Geisel respondeu que "a tendência é ficar com a pior hipótese [...] Pode-se fazer a suposição de que fizeram o enforcamento e resolveram continuar, talvez como um desafio" ( D'Araújo e Castro, 1997:377).

31. Ao ser perguntado se era contrário às eleições diretas na época da campanha pelas "Diretas Já", Geisel respondeu que no Brasil a eleição para presidente deveria ser indireta, feita pelo Congresso Nacional ou por um Colégio Eleitoral. Segundo ele, "essa história de democracia plena, absoluta, para o Brasil, é uma ficção" (D'Araújo e Castro, 1997:444-445).

32. Esse apoio militar ao governo civil, garantindo-lhe estabilidade, mas também lhe impondo limites quanto à ação, constitui o que Eliézer Rizzo de Oliveira chama de função tutelar das Forças Armadas. O autor sustenta a hipótese de que essa função tutelar, caracterizada pela presença dos militares no governo Sarney, desenvol- 
veu-se como desdobramento da função de predominância durante o processo de distensão/abertura. No decorrer deste processo, os dirigentes teriam encaminhado as mudanças de forma que o aparelho militar pudesse retirar-se gradativamente do exercício direto do Estado (função de predominância) sem, no entanto, perder a capacidade de influência sobre as decisões governamentais (função tutelar) (Oliveira, 1987b).

33. Segundo Geisel, “Um presidente, agora, não vai poder se apoiar exclusivamente nas Forças Armadas. Nem nos políticos. [...] Bom era no tempo dos reis. O problema da legitimação era simples [...] Depois inventaram esse negócio de povo". Pensamentos de Geisel registrados no Diário de Heitor Ferreira, 16 de fevereiro e setembro de 1972 (Gaspari, 2003:233).

34. É esclarecedora a observação de Werneck Vianna, segundo a qual o processo de transição à democracia revelou os efeitos da modernização autoritária conduzida pelo regime militar. O autor refere-se à degradação da esfera pública: "Chega-se à democracia política sem cultura cívica, sem vida associativa enraizada, sem partidos de massa e, mais grave ainda, sem normas e instituições confiáveis para garantias de reprodução de um sistema democrático" (Werneck Vianna, 2000:150).

\section{REFERÊNCIAS BIBLIOGRÁFICAS}

ALMEIDA, Maria Hermínia T. de. (1983), “Sindicalismo Brasileiro entre a Conservação e a Mudança", in B. Sorj e M. H. T. de Almeida (orgs.), Sociedade e Política Pós-64. São Paulo, Brasiliense.

ALVES, Maria Helena Moreira. (1989), Estado e Oposição no Brasil (1964-1984). Petrópolis, RJ, Vozes.

ARENDT, Hannah. (1979), As Origens do Totalitarismo, o Paroxismo do Poder. Rio de Janeiro, Editora Documentário.

BORGES, Nilson de. (2003), "A Doutrina de Segurança Nacional e os Governos Militares", in J. Ferreira e L. de A. N. Delgado (orgs.), O Tempo da Ditadura: Regime Militare Movimentos Sociais em Fins do Século XX - O Brasil Republicano. Rio de Janeiro, Civilização Brasileira, vol. 4 .

BUZAID, Alfredo. (1972), Da Conjuntura Política Nacional. Conferência proferida na Escola Superior de Guerra, 2 de junho.

CAMPOS, Roberto. (1971), Instituições Políticas nos Países em Desenvolvimento. Palestras proferidas na Escola Superior de Guerra, 26 de agosto e 18 de setembro.

CARDOSO, Fernando Henrique. (1982), “Os Regimes Autoritários na América Latina", in D. Collier (ed.), O Novo Autoritarismo na América Latina. Rio de Janeiro, Paz e Terra. 


\section{Aloysio Carvalho}

CARVALHO, Aloysio Castelo de. (1989), O Governo Médici e o Projeto de Distensão Política (1969-1973). Dissertação de Mestrado, IUPERJ, Rio de Janeiro.

CARVALHO, José Murilo de. (1987), “Militares e Civis: Um Debate além da Constituinte". Cadernos de Conjuntura, $\mathrm{n}^{\mathrm{o}}$ 10, IUPERJ.

CASTRO, Celso. (2002), “As Apreciações do SNI", in C. Castro e M. C. D’Araújo (orgs.), Dossiê Geisel. Rio de Janeiro, Fundação Getulio Vargas Editora.

COELHO, Campos Edmundo. (1976), Em Busca da Identidade: O Exército e a Política na Sociedade Brasileira. Rio de Janeiro, Forense Universitária.

CRUZ, Sebastião Carlos Velasco e. (1978), “Interesses de Classe e Organização Estatal: O Caso do Consplan". Dados, no 18.

_ _ e MARTINS, C. E. (1983), “De Castelo a Figueiredo: Uma Incursão na Pré-História da Abertura", in B. Sorj e M. H. T. de Almeida (orgs.), Sociedade e Política no Brasil Pós-64. São Paulo, Brasiliense.

CYSNE, Rubens Penha. (1994), "A Economia Brasileira no Período Militar", in G. A. D. Soares e M. C. D'Araújo (orgs.), 21 Anos de Regime Militar: Balanços e Perspectivas. Rio de Janeiro, Fundação Getulio Vargas Editora.

D'ARAÚJO, Maria Celina. (2002), "Ministério da Justiça, o Lado Duro da Transição", in C. Castro e M. C. D’Araújo (orgs.), Dossiê Geisel. Rio de Janeiro, Fundação Getulio Vargas Editora.

__ e CASTRO, Celso (orgs.). (1997), Ernesto Geisel. Rio de Janeiro, Fundação Getulio Vargas Editora.

DINIZ, Eli. (1994), "Empresariado, Regime Autoritário e Modernização Capitalista: 1964-85", in G. A. D. Soares e M. C. D'Araújo (orgs.), 21 Anos de Regime Militar: Balanços e Perspectivas. Rio de Janeiro, Fundação Getulio Vargas Editora.

e LIMA JUNIOR, Olavo B. de. (1986), “Modernização Autoritária: O Empresariado e a Intervenção do Estado na Economia". Série Estudos, no 47, IUPERJ.

FARIA, Vilmar. (1983), “Desenvolvimento, Urbanização e Mudanças na Estrutura do Emprego: A Experiência Brasileira dos Últimos Trinta Anos", in B. Sorj e M. H. T. de Almeida (orgs.), Sociedade e Política Pós-64. São Paulo, Brasiliense.

FICO, Carlos. (2003), “Espionagem, Polícia Política, Censura e Propaganda”, in J. Ferreira e L. de A. N. Delgado (orgs.), O Tempo da Ditadura: Regime Militar e Movimentos Sociais em Fins do Século XX - O Brasil Republicano. Rio de Janeiro, Civilização Brasileira, vol. 4.

. (2004), Além do Golpe: A Tomada do Poder em 31 de Março de 1964 e a Ditadura Militar. Rio de Janeiro, Record.

FLEISCHER, David. (1994), “Manipulações Casuísticas do Sistema Eleitoral durante o Período Militar, ou como Usualmente o Feitiço se Volta contra o Feiticeiro", in G. A. D. Soares e M. C. D'Araújo (orgs.), 21 Anos de Regime Militar: Balanços e Perspectivas. Rio de Janeiro, Fundação Getulio Vargas Editora.

GASPARI, Helio. (2003), A Ditadura Derrotada. São Paulo, Companhia das Letras. 
GÓES, Walder de. (1988), "Militares e Política, uma Estratégia para a Democracia", in F. W. Reis e G. O'Donnell (orgs.), A Democracia no Brasil: Dilemas e Perspectivas. São Paulo, Vértice.

KINZO, Maria D’ Alva Gil. (1994), “O Legado Oposicionista do MDB, o Partido do Movimento Democrático Brasileiro”, in G. A. D. Soares e M. C. D'Araújo (orgs.), 21 Anos de Regime Militar: Balanços e Perspectivas. Rio de Janeiro, Fundação Getulio Vargas Editora.

LAFER, Celso. (1975), O Sistema Político Brasileiro. São Paulo, Perspectiva.

LAMOUNIER, Bolivar. (1988), “O Brasil Autoritário Revisitado: O Impacto das Eleições sobre a Abertura", in A. Stepan (org.), Democratizando o Brasil. Rio de Janeiro, Paz e Terra.

MARTINS, Luciano. (1988), "A Liberalização do Regime Autoritário no Brasil”, in G. O'Donnell, P. Schmitter e L. Whitehead (eds.), Transições do Regime Autoritário: América Latina. São Paulo, Vértice.

O'DONNELL, G. e SCHMITTER, P. (1988), Transições do Regime Autoritário: Primeiras Conclusões. São Paulo, Vértice.

OLIVEIRA, Eliézer Rizzo de. (1987a), “Constituinte, Forças Armadas e Autonomia Militar", in E. R. de Oliveira et alii, As Forças Armadas no Brasil. Rio de Janeiro, Espaço e Tempo.

. (1987b), “O Aparelho Militar: Papel Tutelar na Nova República”, in J. Q. de Moraes et alii, A Tutela Militar. São Paulo, Vértice.

PESSANHA, Charles. (2002), "O Poder Executivo e o Processo Legislativo nas Constituições Brasileiras: Teoria e Prática", in L. W. Vianna (org.), A Democracia e os Três Poderes no Brasil. Belo Horizonte/Rio de Janeiro, Ed. UFMG/IUPERJ/FAPERJ.

SANTOS, Wanderley Guilherme dos. (1978), Crônica do Autoritarismo Brasileiro. Rio de Janeiro, Forense Universitária.

SKIDMORE, Thomas E. (1988), Brasil: De Castelo a Tancredo, 1964-1985. Rio de Janeiro, Paz e Terra.

STEPAN, Alfred. (1986), Os Militares: Da Abertura à Nova República. Rio de Janeiro, Paz e Terra.

TRINDADE, Hélgio. (1994), “O Radicalismo Militar em 64 e a Nova Tentação Fascista”, in G. A. D. Soares e M. C. D'Araújo (orgs.), 21 Anos de Regime Militar: Balanços e Perspectivas. Rio de Janeiro, Fundação Getulio Vargas Editora.

WERNECK VIANNA, Luiz. (2000), “República e Civilização Brasileira”, in N. Bignotto (org.), Pensar a República. Belo Horizonte, Ed. UFMG. 
Aloysio Carvalho

\section{GLOSSÁRIO}

ARENA - Aliança Renovadora Nacional

MDB - Movimento Democrático Brasileiro

PCB - Partido Comunista Brasileiro

PC do B - Partido Comunista do Brasil

PDS - Partido Democrático Social

PDT - Partido Democrático Trabalhista

PFL - Partido da Frente Liberal

PMDB - Partido do Movimento Democrático Brasileiro

PSD - Partido Social Democrático

PT - Partido dos Trabalhadores

PTB - Partido Trabalhista Brasileiro

UDN - União Democrática Nacional 


\section{ABSTRACT}

Geisel, Figueiredo, and the Liberalization of the Authoritarian Regime in Brazil (1974-1985)

This article discusses the evolution of the authoritarian regime in Brazil and the reasons for the liberalization that began in 1974, reconstituting the conflicts and dilemmas faced by the military as government. The leaders were seeking to expand the regime's legitimacy by way of electoral performance when they opted for liberalization, conceived in the wake of a favorable trend in the economy. The liberalization project was conditioned on the institutionalization of a type of post-authoritarian regime with restrictions on democracy and which provided not only for the Armed Forces' retreat from heading the state, but also for their replacement by a trustworthy civilian arrangement based on the government's party, so as to preserve the institutional interests of the military corporations.

Key words: authoritarian regime; military; liberalization; legitimacy

\section{RÉSUMÉ}

Geisel, Figueiredo et la Libéralisation du Régime Autoritaire (1974-1985)

Dans cet article, on discute l'évolution du régime autoritaire et les raisons de la libéralisation commencée en 1974, reprenant les conflits et les dilemmes qu'ont rencontrés les militaires pendant leur gouvernement. Ces dirigeants ont cherché à élargir la légitimité du régime en adoptant la voie des élections, lorsqu'ils ont admis la libéralisation politique, conçue à la suite d'une phase économique favorable. Le projet de libéralisation était astreint à la mise en place d'un type de régime post-autoritaire restreignant la démocratie; il prévoyait non seulement le retrait de l'Armée de la direction de l'État, mais aussi son remplacement par un groupe civil de sa confiance choisi dans le parti du gouvernement, de façon à préserver les intérêts institutionnels des corporations militaires.

Mots-clé: régime autoritaire; militaires; libéralisation; légitimité 